\title{
Awareness Level of Visually Impaired College Students about Urdu Poets and Poetry in Punjab: A Qualitative Inquiry
}

\author{
${ }^{1}$ Muhammad Jahanzaib, ${ }^{2}$ Samina Ashraf, ${ }^{3}$ Ghulam Fatima \\ ${ }^{1}$ Ph.D. Scholar, Department of Special Education, University of Punjab, Lahore Pakistan, m.zaib92@gmail.com \\ ${ }^{2}$ Assistant Professor, Department of Special Education, University of Punjab, Lahore Pakistan, \\ samina.dse@pu.edu.pk \\ ${ }^{3}$ Associate Professor, Institute of Education and Research, University of Punjab, Lahore Pakistan, \\ fatima.dse@pu.edu.pk
}

\begin{abstract}
ARTICLE DETAILS
History

Revised format: August 2020

Available Online: September 2020

Keywords
Awareness level, visually
impaired students, Urdu poetry
\end{abstract}

JEL Classification

$I 0, I 2$

\section{ABSTRACT}

Language has been the most popular source of communication in human society since the start of civilization. The tradition of Folk Tales appeared as the foundation of literature in ancient times. Poetry is a significant way of expression in human literature. Urdu language possesses uncountable master pieces of prose and poetry. Visually impaired persons have proved themselves as literature lovers, good readers and visionary poets in past and present. This study is an effort to depict the awareness level of visually impaired college students about Urdu poets and their creations. The population of the study consisted of all visually impaired students enrolled in public and private sector colleges located in the district Lahore and Okara. A self-developed and validated structured interview schedule containing 10 open ended questions was used to collect data from conveniently selected sample of 30 visually impaired students (males $=18$, females=12). Descriptive statistics (percentages of responses) were calculated, collected information was coded; major themes were derived and interpreted by qualitative data analysis technique. The Study reflected that the visually impaired college students were having a lot of information about Urdu poets and their creations although there seemed a lack of in depth knowledge. They reported the lack of talking books and material in Braille on Urdu poetry of great and famous poets. They suggested the establishment of talking libraries throughout the country. Major findings were reported, conclusions were drawn and recommendations were made to Punjab Higher Education Department.

\section{OPEN ACCESS}

(C) 2020 Center for Sustainability Research and Consultancy Pakistan under a Creative Commons Attribution-NonCommercial-ShareAlike 4.0

Corresponding author's email address: fatima.dse@ pu.edu.pk

Recommended citation: Jahanzaib, M., Ashraf, S. \& Fatima, G. (2020). Awareness Level of Visually Impaired College Students about Urdu Poets and Poetry in Punjab: A Qualitative Inquiry. Journal of Business and Social Review in Emerging Economies, 6(3), 1148-1152 


\section{Introduction}

Pen and paper have been considered as the basic tools of communication in all eras of human civilization. Man learnt to express his thoughts in the form of pictorial and symbolic representation even in Stone Age. With the passage of time the body of knowledge has been expanded in written form. In result a large number of unforgettable hand written books were appeared in various parts of the word. After the invention of printing press in $15^{\text {th }}$ century publishing became an art or industry. Human literature was born with the birth of human being. Many shapes of literature were evolved before appearance of published books. After that various modern forms of literature were appeared in the shape of prose and poetry. Book reading is considered as a great source of knowledge similarly a very interesting hobby among the people of different age groups and each sector of society. Usually people keep in touch with book reading across their life span as a basic source of knowledge or pleasure. Different societies had different areas of interest according to their specific norms.

Many visionary poets, Philosophers and thinkers performed their leading role in various movements of reforms. In this way they possessed an unforgettable and irreplaceable position in the hearts of their people. On the other hand, book reading entered in a new phase during the last few decades of $20^{\text {th }}$ century under the influence of electronic media. Book reading was replaced in this age with drama and film at large scale. Since the start of $21^{\text {st }}$ century another emerging media industry attracted the people's attention towards it that is social media. Today world became a global village due to modern sources of communication as well as transportation. Various IT devices and sources of communication captured the people's attention. In this way the reading trend reshaped once again. Computer and mobile technology opened the new horizons of knowledge gaining and pleasure seeking for peoples of all age groups by different means of communication like YouTube, WhatsApp, Facebook, twitter etc. In this scenario a large amount of people attracted towards e learning. Particularly youngster and students depend on electronic devices for knowledge gaining and pleasure seeking. In this modern era reading habits of people especially of students are changed in many ways. As Ashfaq and Ansari (2018) reported that the reading behavior of the online readers is in transition as the Internet surfing has increased non-sequential reading, interactive reading, superficial reading, and extensive reading and at the same rates is responsible for decreasing concentrated and in-depth reading. Also the Internet surfing has increased reading of the news \& views, general knowledge, selected fields, sexual content, spiritual/religious text and has decreased reading of literature (Loan \& F.A, 2012). In the same way people with vision impairment, introduced usually as literature lovers are changing their reading habits as well. Often they have strong relation with sonic devices like radio, TV, recorded material and screen reader but the impact of electronic devices on reading habits of students with vision impairment is still an interesting question. In this case, Adetoro (2010) narrated that adults with vision impairment had high reading interests in religious, business and entertainment materials among others. Secondary school respondents had high reading interest in art subjects, reference materials, manuals and animal story materials etc. In the light of above discussion, it is concluded that the impact of IT devices on reading habits of visually impaired students, their preference among various reading tools and their level of understanding and attachment for different kinds of literature are important and interesting researchable topics. The present study is an effort to describe the awareness level of vision impaired college students about Urdu poets and poetry in Punjab Pakistan.

\section{Review of Related Literature}

It is an evidence based fact that present word is the world of technology. Information Technology influenced all the sectors of society at significant level. But in-spite of IT revolution, printed Books are still maintained. Tahir, Mahmood and Shifique (2008) revealed that majority of the teaching staff belonging from humanities departments depends mostly on books. Print was the most used mode for them. But at the same time the influence of IT devices is undeniable particularly in education sector where the teaching-learning tools, classroom strategies, pedagogy and instructional material have been modified today. There could be seen a notable impact of IT technology on reading habits and reading interest of students. As F.A. (2012) reported that the reading attitude of students in online reading is in the process of change like Internet browsing has expanded for the sake of random reading, reciprocal reading, trivial reading, and purposes-less lengthy reading and at similar level it is liable to reduce focused and deep reading. Additionally, the Internet surfing has expanded to visit the news, people opinions, common information, scared/clerical content and has diminished study of literature. 
Moreover, another study indicated that higher secondary and graduation level EFL (English as a Foreign Language) student's reading manner replaced printed text by online reading. $83.9 \%$ of learners read web based material daily and $69.3 \%$ of them check their mails and online messages daily. On the other hand, just $31.4 \%$ from them read newspaper; similarly $33.1 \%$ students read magazines consistently (Shen, 2006). Similarly, another study reflected some different aspects about the impact of E-learning on reading habits and reading interest of students studying in tertiary education institutions. The declining engagements in reading by learners at tertiary education institutions is a serious question for everyone, as it influences the academic norms and the quality of our academic product sent into the general public. The study depicts that electronic books, online research publications and web based news are the most popular online modes among the learners. Online data hubs are frequently used among learners. When attempting to discover are an example of the reading pattern of students, majority of the learners read under two hours every day (Ajayi et al, 2014).

On the other hand, in spite of declining interest in reading and intensive interest in some controversial topics like sexual material, shown by students. Some researchers elaborated many positive impacts of e-learning on reading habits in this source of E learning decrease the workload on the libraries and their resources. Similarly, anybody can read or study anything even during journey at anywhere in the world. Conventional libraries and E-libraries are compatible with each other to address the issues of different sort of learners. Youngster often like study by E-resources or by critical analysis of various books these all means of communication and learning improve the reading attitude (Verma \& Malviya, 2010).

Similarly, Ansari (2018) supported the statement of Verma and Malviya (2010) that the online readings via web enhances the reading tendency and increases the awareness level of readers with the accessibility of knowledge worldwide. Furthermore, e-lessons, classes, and sample lectures are enhancing the self-sufficient long lasting learning capabilities. Moreover, paraphrasing provisions, e-dictionaries, exercises for articulation and word memory improve the language abilities as well.

\section{Objectives of the Study}

The study was conducted:

1. To know the level of awareness about Urdu poets among visually impaired persons.

2. To study which kind of poetry is liked by visually impaired persons.

3. To identify their level of awareness about the work of Urdu poets.

4. To explore their level of awareness about ancient and modern poets.

\section{Research Questions}

1. What is level of awareness about Urdu poets among visually impaired persons?

2. Which kind of poetry is liked by visually impaired persons?

3. What is their level of awareness about the work of Urdu poets?

4. What is their level of awareness about ancient and modern poets?

\section{Methodology}

The present study was conducted to explore the awareness level of visually impaired college students about Urdu poets and literature produced by them. The study in your hands is descriptive research by nature. Researchers has preferred qualitative interview method to know the awareness level of college going visually impaired students about Urdu poets and poetry because Taylor and Bogdan quoted Benney and Hughes (1970) as " The interview is the favored digging tool of social researchers"(Taylor \& Bogdan, 2015).

\subsection{Population of the Study}

The target population of the study consisted of visually impaired college students of Punjab. The accessible population of the study was consisted of visually impaired college students studying at graduation and post-graduation level in public and private colleges of conveniently selected two districts Lahore and Okara.

\subsection{Sample}

In order to assure comprehensive representation of population, the convenient sampling technique was applied to 
extract the sample of the study. For the selection of sample two districts Lahore and Okara were conveniently selected. From both districts the researchers randomly selected 15colleges including 10 public and five private colleges. From the selected 15 colleges30 available visually impaired students including 18 males and 12 females were purposely selected.

\subsection{Data Collection}

For the purpose of data collection, self-administered and validated structured interviews were taken from 30 college students with vision impairment studied in different public and private colleges of two districts of Punjab, Okara and Lahore. Researchers took most of the interviews themselves. Some interviews were conducted with the help of coresearchers but probing items of all structured interviews were same.

\subsection{Data Analysis}

For the sake of data analysis, at the first step the percentages of responses were calculated, at the second step the qualitative data analysis technique was carried out, data were coded and four major themes were derived as follows; an ordinary level of awareness was found, lack of in-depth awareness, reading trend has changed by electronic media and resources and reading opportunities for students with vision impairment should be enhanced.

\section{Findings and Results}

Some of the important findings of this research are as follows

1. Some $(33.33 \%)$ of students with vision impairment responded that Poem has only one topic whereas Ghazal has many topics.

2. The majority (76\%) of students with vision impairment like to read Ghazal.

3. Some $(43 \%)$ of students with vision impairment have awareness of Bang-e-Dura.

4. The majority $(60 \%)$ of students with vision impairment responded that Allama Iqbal is a modern poet.

5. Mostly (70\%) of students with vision impairment could not recognize the pieces of poetry with name of books and poets.

6. Some (39\%) of students with vision impairment reported that they often read academic and informative material through internet but they had less interest in literary books.

7. Majority (75\%) had basic knowledge about Urdu poetry and poets.

\section{Discussion}

The present study support and contradict different previous researches in many ways. The finding about transformation in student's reading interest and reading habit support the finding of Loan \& F.A. (2012) who reported that the reading attitude of students in online reading is in the process of change and it is liable to reduce focused and deep reading. Our study depicted that VI students has basic knowledge about Urdu poetry endorse the finding of Maryam who told that reading is one of the most favorite hobbies in students with vision impairment. Students in Pakistan mostly choose Urdu language for reading. On the other hand Maryam reported that a lot of hindrances are faced while reading like inaccessibility of books and their translated publications, scarcity of talking and brail books absence of assistant in library etc. Similarly, Braille materials (69.9\%) and talking books/audio recordings (43.5\%) were not readily available in the libraries. The present study gave its 1st and last recommendations in this way. Awareness may be provided to visually impaired persons about Urdu poetry by transcribing it into Braille and audio recording. Library assistants should be provided to students with vision impairment in all public libraries.

\section{Conclusions}

Students with vision impairment had a lot of knowledge about urdu poetry. They mostly like Ghazal in poetry. Allama Iqbal is the most favorite poet among visually impaired persons. Bang-e-Dura is mostly read by visually impaired persons from the books of Allama Iqbal. Dewan-e-Ghalib is the most popular book among visually impaired persons. Information technology reshaped the visually impaired student's reading interest that they do various academic and pleasure seeking activities but they lose their interest in in-depth reading and literary books. 


\section{Recommendations}

Following are the recommendations on the basis of research findings:

1. Awareness may be provided to visually impaired persons about urdu poetry by transcribing it into Braille and audio recording.

2. Comprehensive and easy translations of Urdu classical poems may be provided to the visually impaired persons.

3. Literary activities like Bait-Bazi and Mushaira (poetic competitions) may be organized in every educational institution.

4. Prominent participation may be given to visually impaired students in all literary activities and performances at every occasions and celebrations in college.

5. Visually impaired Urdu poets may be granted or encouraged by authorities and Government.

6. Library assistants should be provided to student with vision impairment in all public libraries

\section{References}

Adetoro, N. (2010). Reading interest and information needs of persons with vision impairment in Nigeria. South African Journal of Libraries and Information Science, 76(1), 49-56.

Adetoro, N. (2011). Availability and use of information materials by persons with visually impairment in Nigeria. Information Society and Justice, 4(2), 5-18.

Ansari, M. N. (2018). Impact of Online Reading on Skills of Professionals.

Ansari, M. N. (2018). Impact of Online Reading on Skills of Professionals.

Ashfaq, H., \& Ansari, M. N. (2018). Impact of Online Reading on Skills of Professionals. Library Philosophy and Practice.

Ashfaq, H., \& Ansari, M. N. (2018). Impact of Online Reading on Skills of Professionals. Library Philosophy and Practice.

Brazier, H., \& Owen, V. (2000). Library provision for visually impaired in the UK and Canada: National services and international cooperation. Alexandria, 12(2), 71-80.

Chauhan, P., \&Lal, P. (2012). Impact of information technology on reading habits of college students. International Journal of research review in engineering science and technology, 1(1), 101-106.

Guthrie, J. T., McGough, K., Bennett, L., \& Rice, M. E. (1996). Concept-oriented reading instruction: An integrated curriculum to develop motivations and strategies for reading. Developing engaged readers in school and home communities, 165-190.

Kinnell, M., Yu, L., \& Creaser, C. (2000). Public library services for visually impaired people. Library \& Information Statistics Unit, Department of Information and Library Studies, Loughborough University.

Liu, Z. (2005). Reading behavior in the digital environment. Journal of documentation.

Loan, F. A. (2012). Impact of the Internet surfing on reading practices and choices. Webology, 9(1), 1-10.

Onovughe, O. G. (2012). Internet use and reading habits of higher institution students. Journal of emerging trends in educational research and policy studies, 3(1), 11-15.

Radojichikj, D. D. (2015). Students with vision impairments: Braille reading rate. International Journal of Cognitive Research in Science, Engineering and Education, 3(1), 1-5.

Ryles, R. (1996). The impact of braille reading skills on employment, income, education, and reading habits. Journal of vision impairment and blindness, 90, 219-226.

Shen, L. (2006). Computer technology and college students' reading habits. Chia-Nan Annual Bulletin, 32, $559-572$.

Tahir, M., Mahmood, K., \&Shafique, F. (2008). Information needs and information-seeking behavior of arts and humanities teachers: A survey of the University of the Punjab, Lahore, Pakistan. Library Philosophy and Practice, 227(12), 1-11.

Verma, J., \&Malviya, V. (2014). The impact of internet and digital media on reading habit. In XXIV National Seminar of the IASLIC (Vol. 50).

Zia, M. W. (2019). Reading Habits of Blinds and Visually Impaired Students of University of Karachi. Library Philosophy and Practice, 1-11. 